\title{
Review and Critical Evaluation of Cognitive Behavioural Therapy for the Treatment of Post-Traumatic Stress Disorder
}

\author{
Gina Marie Piane ${ }^{1}$, Precious Chidozie Azubuike ${ }^{2 *}$ \\ ${ }^{1}$ Department of Community Health, College of Professional Studies, National University, San \\ Diego, California \\ ${ }^{2}$ Department of Reproductive Health Sciences, Institute of Life and Earth Sciences, Pan \\ African University, Ibadan, Nigeria
}

\begin{abstract}
This systematic analysis seeks to describe the evidence regarding cognitive-behavioral therapy (CBT) for the treatment of post-traumatic stress disorder (PTSD) in the recent, published, professional literature. This systematic review addressed the question of the efficacy of and evidence for CBT for the treatment of PTSD. The review incorporates a comprehensive literature review, addresses the methodological quality of the papers, and synthesizes the results by themes. After evaluation of the published and professional literature, five themes; Result of CBT for PTSD, Alternatives to CBT for PTSD, CBT in practice, Treatment of children, and CBT in tandem with medication. 11 published studies including qualitative interviews, randomized control trials, and meta-analyses were examined. CBT proved to be instrumental in alleviating PTSD symptoms in men who have been exposed to combat trauma, women who have experienced violence, veterans who have gone through combat trauma and also have disorders due to addictions, and young adults and children who have experienced trauma. Studies have shown that CBT works quite well in the case of couples where one has been diagnosed with PTSD. CBT for PTSD can be delivered face-to-face or by using telepsychiatry. CBT tends to have a higher success rate when carried out while administering appropriate drugs. Also, carrying out CBT for PTSD can bring about stronger relationships and posttraumatic stress growth.
\end{abstract}

Keywords: Cognitive Behavioral Therapy, Post-Traumatic Stress Disorder, Treatment.

\section{Introduction}

Formerly grouped under anxiety disorder alongside generalized anxiety, phobia, and panic, Post-Traumatic Stress Disorder (PTSD) has in recent times been classified as Stressor and Trauma-Related Disorders since it is associated with traumatic events [1]. To be diagnosed with PTSD, "a person must have experienced, witnessed, or been confronted with an event so traumatizing that it results in symptoms or re-experiencing, hyperarousal, cognitive alterations or avoidance" [1].

Cognitive Behavioral Therapy (CBT), originated by Dr. Aaron T. Beck in the 1960s, has often been employed to treat PostTraumatic Stress Disorder (PTSD) [1]. CBT seeks to annul the undesirable, abnormal thoughts resulting from the trauma in order to enhance adaptation to cognition and behaviors [2]. This systematic analysis demonstrates the approval of CBT for PTSD in the recent, published, professional literature. According to [3], the traumatic events that lead to PTSD include violent personal assaults, natural or human-caused disasters, accidents, combat, and other forms of violence. Although PTSD stands at a figure of just $3.6 \%$ per year and $6.8 \%$ over the lifetime, about half of the adults of the world population have experienced it. The 
prevalence is higher among females and people aged 45-59 years. Variants of a gene, FKBP5, can predispose an individual to PTSD [1]. Also, early childhood trauma or abuse can also play a part in making one susceptible to PTSD [1].

Psychological therapies for PTSD include psychodynamic treatment, CBT, counselling, and family-based therapy. CBT has been found to be particularly effective [2]. There have been analysis of PTSD treatments, and conclusions have been drawn that successful treatment includes five components; addressing safety, calming, efforts to support self and collective efficacy, fostering connectedness, and instilling hope [1]. Treatment for PTSD has been described as psychotherapy, medications, or both [3]. The psychotherapy described includes CBT, particularly the components of exposure therapy and cognitive restructuring.

\section{Aim/Purpose}

This systematic analysis serves as proof that cognitive-behavioral therapy (CBT) is effective in the treatment of PTSD. This systematic review answered the questions being asked concerning the potency and evidence of CBT in the treatment of PTSD. The review incorporates a thorough literature review, gives the methodological rating of the papers, and produces the outcomes by themes.

\section{Review Question}

Does the published professional literature support the potency of CBT for PTSD?

\section{Materials and Methods}

This systematic review cleared the doubts about the treatment of PTSD using CBT. It entailed a comprehensive search of the literature, stated the methodological quality of the papers, and produced the results by themes. In March 2019, an examination of the professional published articles in CINAHL, Health Source, Medline in EBSCO, ProQuest Health, Medical Complete, and the Cochrane Collaboration was carried out. 'Cognitive Behavioral Therapy for PTSD' and 'Cognitive
Behavioral Therapy for PTSD Cochrane' were searched for on the databases. Journal articles published between 2002 and 2019 were included in the search, which also was restricted to articles published in English. Given the fact that this is a systematic review of the published literature, approval by the National University Institutional Review Board was not warranted.

\section{Results}

Five themes emerged from the analyzed, published, professional literature, and the articles were sorted accordingly; Results of CBT for PTSD, Alternatives to CBT for PTSD, CBT in practice, Treatment of children, and CBT together with medication.

\section{Outcomes of CBT}

A randomized control trial that comprised of 150 women diagnosed with PTSD and symptoms of depression was conducted by [4]. From their tests, they discovered that CBT for women who were at risk for Intimate Partner Violence (IPV) could break what they refer to as the 'vicious cycle of abuse'. Their manualbased treatment included detailed written accounts, daily readings of these accounts, and helping the clients identify cognitive distortions and to promote balanced thinking. The treatment group was at lower risk for subsequent IPV than the controls. They posit that CBT may lower the risk by increasing positive outcomes such as accurate perceptions of situations and increased safety behaviors.

In the descriptive case studies produced by [5], there is preliminary evidence that CBT enhanced by the inclusion of significant others (SOs) can be a promising approach for veterans with both PTSD and alcohol use disorders. The sample was drawn from those who served in Operation Enduring Freedom (OEF) and Operation Iraqi Freedom (OIF). The intervention entailed psychoeducation about PTSD, alcohol misuse, the signs of PTSD that lead to social stigmatisation and emotional 
numbing, and also the need for social support. The SOs were included to offer support consistent with the veteran's treatment goals. Some examples included helping the veteran to avoid alcohol use, practicing new coping skills, engaging in alternative activities, communication skills, and problem-solving.

In 2012, A Study added to the numerous proofs regarding partner inclusion in the remedy of PTSD [6]. Their randomized control trial, which drew clients from a Veteran's Affairs (VA) hospital and a university research center, offered a 15-session cognitivebehavioral therapy for couples with one partner who was diagnosed with PTSD. They labeled this intervention as disorder-specific couple therapy' and found significant improvement in PTSD symptom severity in the intervention as compared to the wait-list. The cognitivebehavioral couple treatment began with psychoeducation regarding PTSD and its effect on constituents of the relationship. It went ahead to the evaluation of avoidance of feelings and enhanced communication. In time the couple was guided to approach rather than avoid specific people, places, situations, and emotions that have been evaded as a couple because of PTSD. In the final phase of treatment, the couples were guided to challenge their cognitions and strong tenets that maintain PTSD, specifically, trust, control, emotional closeness, and physical intimacy.

Further analyses of the same randomized control trial with couples were conducted [7] and [8]. The 2014 analysis found that the partners too benefitted from the couple therapy. Those who presented with clinical levels of distress at pre-treatment benefitted significantly, as shown by improvements in psychological functioning [7]. In the 2016 analysis, the investigators took a very different approach in measuring post-traumatic growth and not the traditional approach of measuring distress decrease. The measurement of posttraumatic growth involved perceptions about relations to others, perceptions of new possibilities, personal strength, spiritual change, and appreciation of life [8]. They discovered that CBT Couple Therapy for PTSD not only diminished symptoms and misery but also brought about a significant increase in posttraumatic growth.

Benitez and colleagues focused their investigation on the efficacy of CBT for PTSD in reducing somatization [9]. Using the Clinician Global Impression of Change Scale, which addresses headaches, fatigue, shortness of breath, nausea, and musculoskeletal symptoms, they measured the extent of somatization. Their research demonstrated that CBT was acceptable and feasible for their Latino clients. In addition, the effect size, preand post-treatment, was higher for the reduction of somatic symptoms than for the reduction of PTSD severity.

It is estimated that more than half of individuals with PTSD experience disturbed sleep. Some speculate that insomnia may be caused by nightmares associated with fear and arousal conditioning. [10] examined the persistence of insomnia after CBT for PTSD. They discovered that even when the nightmares and hypervigilance that come with PTSD cease, insomnia continued in $48 \%$ of their client's post-treatment. Added to this, if the initial trauma was sleep-related, the clients faired worse. This may imply that a specialized intervention for insomnia post-CBT for PTSD is needed.

\section{Alternative Treatments}

Another option to CBT for PTSD that has been used for approximately 20 years is an approach known as psychological debriefing or Critical Incident Stress Debriefing. These techniques, which use a single session, originated in the military unit's post-combat to maintain group morale and to reduce psychiatric distress among soldiers. The National Institute of Mental Health performed a meta-analysis for the Cochrane Collaboration of 15 RCTs measuring how effective debriefing 
sessions are [11]. They concluded that just one session debriefing for an individual is not a supported technique and hence, is not a feasible alternative to CBT for PTSD.

Another alternative to CBT for PTSD is Eye Movement Desensitization and Reprocessing (EMDR), which the World Health Organization (WHO) has determined to be among the best therapies for PTSD. EMDR is effective in combatting undesirable feelings, arousal, despondency, and agitation [12]. In a metaanalysis of 14 RCTs of EMDR for PTSD, Khan and colleagues came to realize that the participants who were administered EMDR experienced reduced symptoms of PTSD significantly more than those treated with CBT. This difference, however, was not evident at the 3-month follow-up. They conclude that more robust clinical trials of EMDR are warranted, seeing that it is likely to be a superior treatment for PTSD.

\section{CBT in Practice}

CBT for PTSD may be administered in the traditional manner, face-to-face, or employing teleconferencing technology. To determine if either means had more fidelity with the manualized CBT, [13] in 2013 performed a confirmatory analysis from an RCT where some clients were treated using telepsychiatry while others were counseling face-to-face in a single room. Their results indicate that the therapists in either setting adhered to the manual and were equally competent in delivering CBT [13].

\section{Treatment of Children}

PTSD is common among children and adolescents who have experienced trauma. In a Cochrane collaboration, the credibility of psychological therapies for treating PTSD in young adults and children was the subject of a meta-analysis. After realizing the outcomes of 14 RCTs, they concluded that psychotherapies for young adults and children with PTSD are effective [2]. However, they did not find CBT to be superior to any other psychological treatment method such as exposure-based therapy, psychodynamic therapy, narrative therapy, supportive counselling, family-based therapy, and eye movement desensitization and reprocessing [2].

\section{CBT Combined with Medication}

A Study [14] reported on an RCT that compared treatments of CBT with sertraline and CBT with pill placebo. They measured a significantly greater improvement in PTSD symptoms in the CBT combined with the medication group. This improvement persisted at the 6-month follow-up, indicating a longterm decrease in symptoms.

\section{Discussion}

The evidence regarding the effectiveness of CBT for PTSD is robust. There is consistency among the meta-analyses, randomized clinical trials, qualitative interviews, and case studies. Experiencing traumatic events is very rampant, and approximately 12.6 million individuals in the United States are diagnosed with PTSD each year. The prevalence is higher among females and people ages 45-59 years. The samples contained genders, age groups, minorities, and international samples, and many individuals across different sectors benefitted from the therapy. Women have a few times higher danger of suffering post-traumatic stress disorder (PTSD) contrasted with men, and few components are included clarifying this distinction [15]. Both psychosocial and organic clarifications (for example, oxytocin related) have been proposed in different articles. Nonetheless, a requirement for genderand sex-sensitive examination and announcing still exists. [12] had uncovered that the lifetime predominance of PTSD is around $10-12 \%$ in ladies and 5-6\% in men. There are comparative contrasts between the genders for (comorbid) issues, for instance, significant depression and nervousness issues. PTSD subcluster scores have been discovered to be expanded in ladies, 
for instance, for re-encountering and anxiousness [16]. People experience various kinds of trauma, both in private life and at work (for example, cops) [17], with ladies being exposed to high impact trauma (for example, sexual trauma) than men are, at a much younger age. Injury from the get-go in life has more effect, particularly when it includes type II injury meddling with the neurobiological turn of events and character. [18] adds that traumatic stress influences various spaces of the cerebrums of young men and young ladies at various ages.

CBT for PTSD was also shown to be effective with children, adolescents, and female victims of intimate partner violence (IVP). Therapy for teenagers or children who have gone through trauma or abuse may be especially crucial since these experiences in childhood predispose the child to PTSD later in life. Treatment of ladies who experienced IPV also has a preventive component in that those treated with CBT are not likely to experience PTSD later on in life. CBT for PTSD not only treats the present trauma and symptoms but has benefits throughout the client's lifespan. Studies have discovered that CBT assists with diminishing self-announced PTSD seriousness and related nervousness and that members do not consult experts for a PTSD conclusion at follow-up evaluations, showing supported improvement [19]. Curiously, it has been reported that CBT affects the physiological boundaries associated with PTSD, recommending improvement. Numerous examinations have investigated these zones and detailed a more prominent abatement of pulse reactivity and significant increase of systolic circulatory strain reaction to orthostasis after CBT in PTSD patients [18]. CBT has likewise been proven to be the frighten reaction in PTSD. A huge decrease in electromyographic reactivity to all upgrades was seen, either CBT or steady treatment, either CBT or supportive therapy, compared with wait-list controls [18]. Given this, alarm reactions are suggested as a
PTSD treatment result list [18]. Also, neuropsychological working in people with PTSD have been taken into consideration. Nonresponders to treatment had altogether less fortunate execution on proportions of verbal memory contrasted and responders and further showed account encoding shortages. Verbal memory deficiencies appear to lessen the adequacy of CBT and ought to be considered in its execution.

Among the psychological therapies for PTSD, CBT has been reported to be very effectual. The components of CBT that were taken note of in the research articles varied from study to study. However, the most occurring were: psychoeducation, cognitive restructuring, exposure, communication, anger management, relaxation, and coping skills. Upon the mentioning of the CBT duration, the clients were treated with 10-15 sessions. PTSD also includes five therapeutic components; addressing safety, calming, efforts to support self and collective efficacy, fostering connectedness, and instilling hope.

\section{Limitations of the Review}

This detailed report of the literature is limited by publication bias. Reports in any language other than English were restricted. The date range of published literature to be included was 2002-2019. Therefore, research previously published and currently under review was not included and may represent incongruent conclusions. Publication bias may manifest itself in the absence of publication of research that shows no major discrepancies among treatment groups.

\section{Conclusion}

It has been shown that CBT is quite potent in abating PTSD symptoms in women who have undergone brutality or coercion, men who have passed combat trauma, veterans who have had a taste of combat trauma and have substance use problems, and children and adolescents who have gone through trauma. Studies have shown 
that CBT is quite efficacious with couples where one is diagnosed with PTSD. CBT for PTSD can be administered face-to-face or via telepsychiatry. It may be more promising when combined with medication. In addition, CBT for PTSD can bring about relationship enhancement and post-traumatic growth. CBT is currently the preferred treatment method for therapists treating clients with PTSD.

\section{Conflict of interest(s)}

The authors declare no conflict of interest.

Table 1. Summary of Articles included in the Analysis

\begin{tabular}{|c|c|c|c|}
\hline Author, Title & Theme & Methods & Summary \\
\hline $\begin{array}{l}\text { Iverson, K. M., Gradus, J. L., Resick, } \\
\text { P. A., Suvak, M. K., Smith, K. F., \& } \\
\text { Monson, C. M. (2011). Cognitive-- } \\
\text { behavioral therapy for PTSD and } \\
\text { depression symptoms reduces risk for } \\
\text { future intimate partner violence } \\
\text { among interpersonal trauma survivors. }\end{array}$ & $\begin{array}{l}\text { Outcomes } \\
\text { of CBT }\end{array}$ & $\begin{array}{l}\text { Randomized } \\
\text { Control Trial } \\
(\mathrm{n}=150 \text { women })\end{array}$ & $\begin{array}{l}\text { Decrease in PTSD } \\
\text { symptoms in the course of } \\
\text { treatment were related with } \\
\text { a reduction of Intimate } \\
\text { Partner Violence } \\
\text { victimization. }\end{array}$ \\
\hline $\begin{array}{l}\text { Mcdevitt-Murphy, M., Roberts, M., } \\
\text { Barnett, J., \& Sherman, M. (2011). } \\
\text { Significant Other Enhanced } \\
\text { Cognitive-Behavioral Therapy for } \\
\text { PTSD and Alcohol Misuse in } \\
\text { OEF/OIF Veterans. }\end{array}$ & $\begin{array}{l}\text { Outcomes } \\
\text { of CBT }\end{array}$ & $\begin{array}{l}\text { Descriptive } \\
\text { Case-Studies } \\
(\mathrm{n}=2 \text { men })\end{array}$ & $\begin{array}{l}\text { Preliminary findings show } \\
\text { that integrative treatments } \\
\text { for treating OEF/OIF } \\
\text { veterans with co-occurring } \\
\text { PTSD and alcohol misuse. }\end{array}$ \\
\hline $\begin{array}{l}\text { Monson CM, Fredman SJ, Macdonald } \\
\text { A, Pukay-Martin ND, Resick PA, } \\
\text { Schnurr PP. Effect of Cognitive- } \\
\text { Behavioral Couple Therapy for PTSD: } \\
\text { A Randomized Controlled Trial. }\end{array}$ & $\begin{array}{l}\text { Outcomes } \\
\text { of CBT }\end{array}$ & $\begin{array}{l}\text { Randomized } \\
\text { Control Trial } \\
(\mathrm{n}=40 \text { couples }) *\end{array}$ & $\begin{array}{l}\text { Couples with one partner } \\
\text { diagnosed with PTSD } \\
\text { decreased PTSD symptoms } \\
\text { after disorder-specific } \\
\text { couple therapy. }\end{array}$ \\
\hline $\begin{array}{l}\text { Pérez Benítez, C., Zlotnick, C., } \\
\text { Gomez, J., Rendón, M., \& Swanson, } \\
\text { A. (2013). Cognitive behavioral } \\
\text { therapy for PTSD and somatization: } \\
\text { an open trial. }\end{array}$ & $\begin{array}{l}\text { Outcomes } \\
\text { of CBT }\end{array}$ & $\begin{array}{l}\text { Pre and post } \\
\text { evaluation of a } \\
\text { therapeutic } \\
\text { intervention } \\
(\mathrm{n}=7 \text { women, } 1 \\
\text { man) }\end{array}$ & $\begin{array}{l}\text { Adapted cognitive } \\
\text { behavioral therapy and } \\
\text { abridged somatization } \\
\text { resulted in a small to } \\
\text { moderate reduction in } \\
\text { PTSD severity, and a } \\
\text { moderate to large reduction } \\
\text { of depressive symptoms } \\
\text { and physical functioning. }\end{array}$ \\
\hline $\begin{array}{l}\text { Shnaider, P., Pukay, M. N. D., } \\
\text { Fredman, S. J., Macdonald, A., \& } \\
\text { Monson, C. M. (2014). Effects of } \\
\text { Cognitive-Behavioral Conjoint } \\
\text { Therapy for PTSD on Partners' } \\
\text { Psychological Functioning. }\end{array}$ & $\begin{array}{l}\text { Outcomes } \\
\text { of CBT }\end{array}$ & $\begin{array}{l}\text { Randomized } \\
\text { Control Trial } \\
(\mathrm{n}=40 \text { couples }) \\
*\end{array}$ & $\begin{array}{l}\text { Partners of individual with } \\
\text { PTSD may benefit from } \\
\text { couple treatment for PTSD } \\
\text { and relationship } \\
\text { enhancement. }\end{array}$ \\
\hline $\begin{array}{l}\text { Wagner, A., Torbit, L., Jenzer, T., } \\
\text { Landy, M., Pukay-Martin, N., } \\
\text { Macdonald, A., .. Monson, C. } \\
\text { (2016). The Role of Posttraumatic }\end{array}$ & $\begin{array}{l}\text { Outcomes } \\
\text { of CBT }\end{array}$ & $\begin{array}{l}\text { Randomized } \\
\text { Control Trial } \\
(\mathrm{n}=40 \text { couples }) *\end{array}$ & $\begin{array}{l}\text { Individuals who received } \\
\text { treatment had a significant } \\
\text { increase in Post-Traumatic } \\
\text { Growth. }\end{array}$ \\
\hline
\end{tabular}




\begin{tabular}{|c|c|c|c|}
\hline $\begin{array}{l}\text { Growth in a Randomized Controlled } \\
\text { Trial of Cognitive-Behavioral } \\
\text { Conjoint Therapy for PTSD. }\end{array}$ & & & \\
\hline $\begin{array}{l}\text { Zayfert, C., \&Deviva, J. (2004). } \\
\text { Residual insomnia following } \\
\text { cognitive behavioral therapy for } \\
\text { PTSD. }\end{array}$ & $\begin{array}{l}\text { Outcomes } \\
\text { of CBT }\end{array}$ & $\begin{array}{l}\text { Pre and post } \\
\text { evaluation of a } \\
\text { therapeutic } \\
\text { intervention } \\
(\mathrm{n}=24 \text { women, } 3 \\
\text { men) }\end{array}$ & $\begin{array}{l}\text { CBT for PTSD did not } \\
\text { result in reduction in } \\
\text { insomnia. }\end{array}$ \\
\hline $\begin{array}{l}\text { Rose SC, Bisson J, Churchill R, } \\
\text { Wessely S. Psychological debriefing } \\
\text { for preventing post-traumatic stress } \\
\text { disorder (PTSD). }\end{array}$ & $\begin{array}{l}\text { Alternate } \\
\text { treatments }\end{array}$ & $\begin{array}{l}\text { Meta-Analysis } \\
\text { of Randomized } \\
\text { Control Trials } \\
(15 \text { trials; } n=396 \\
\text { women and } \\
\text { men }) \\
\end{array}$ & $\begin{array}{l}\text { The routine use of single } \\
\text { session debriefing for } \\
\text { trauma victims is not } \\
\text { supported. }\end{array}$ \\
\hline $\begin{array}{l}\text { Khan, A. M., Dar, S., Ahmed, R., } \\
\text { Ramya, B., Mahwish, A., \&Kotapati, } \\
\text { V. P. (2018). Cognitive behavioral } \\
\text { therapy versus eye movement } \\
\text { desensitization and reprocessing in } \\
\text { patients with post-traumatic stress } \\
\text { disorder: Systematic review and meta- } \\
\text { analysis of randomized clinical trials. }\end{array}$ & $\begin{array}{l}\text { Alternate } \\
\text { treatments }\end{array}$ & $\begin{array}{l}\text { Systematic } \\
\text { Review and } \\
\text { Meta-Analysis } \\
\text { of Randomized } \\
\text { Control Trials } \\
\text { (14 trials; } \mathrm{n}=389 \\
\text { women, } 286 \\
\text { men) }\end{array}$ & $\begin{array}{l}\text { Eye Movement } \\
\text { Desensitization and } \\
\text { Reprocessing was more } \\
\text { effective than CBT in } \\
\text { reducing PTSD symptoms. }\end{array}$ \\
\hline $\begin{array}{l}\text { Frueh, B. C., Monnier, J., Grubaugh, } \\
\text { A. L., Elhai, J. D., Yim, E., \& Knapp, } \\
\text { R. (2007). Therapist Adherence and } \\
\text { Competence with Manualized } \\
\text { Cognitive-Behavioral Therapy for } \\
\text { PTSD Delivered via } \\
\text { Videoconferencing Technology. }\end{array}$ & $\begin{array}{l}\text { CBT in } \\
\text { practice }\end{array}$ & $\begin{array}{l}\text { Secondary } \\
\text { Analysis of a } \\
\text { Randomized } \\
\text { Control Trial } \\
\text { (n=38 men) }\end{array}$ & $\begin{array}{l}\text { CBT can effectively and } \\
\text { competently be delivered } \\
\text { by means of telepsychiatry. }\end{array}$ \\
\hline $\begin{array}{l}\text { Gillies D, Taylor F, Gray C, O'Brien } \\
\text { L, D'Abrew N. Psychological } \\
\text { therapies for the treatment of post- } \\
\text { traumatic stress disorder in children } \\
\text { and adolescents. }\end{array}$ & $\begin{array}{l}\text { Treatment } \\
\text { of children }\end{array}$ & $\begin{array}{l}\text { Meta-Analysis } \\
\text { of Randomized } \\
\text { Control Trials } \\
\text { (60 trials; } n= \\
758 \text { adults, } \\
1,155 \text { children) } \\
\end{array}$ & $\begin{array}{l}\text { Fair evidence for the } \\
\text { effectiveness of } \\
\text { psychological therapies, } \\
\text { particularly CBT. }\end{array}$ \\
\hline $\begin{array}{l}\text { Hien, D., Levin, F., Ruglass, L., \& } \\
\text { Lopez-Castro, T. (2015). Enhancing } \\
\text { the effects of cognitive behavioral } \\
\text { therapy for PTSD and alcohol use } \\
\text { disorders with antidepressant } \\
\text { medication: A randomized clinical } \\
\text { trial. }\end{array}$ & $\begin{array}{l}\text { CBT } \\
\text { combined } \\
\text { with } \\
\text { medication }\end{array}$ & $\begin{array}{l}\text { Qualitative } \\
\text { Interviews } \\
\text { ( } \mathrm{n}=69 \text { adults })\end{array}$ & $\begin{array}{l}\text { Participants treated with } \\
\text { 'Seeking Safety' (SS) and } \\
\text { sertraline have greater } \\
\text { improvement than those } \\
\text { treated with SS alone or } \\
\text { placebo. }\end{array}$ \\
\hline
\end{tabular}

*Same trial, various analyses 


\section{Authors Contribution}

Dr. Piane conceptualized the analysis and developed the themes to be included as well as the majority of the writing. Mr. Azubuike contributed to the conceptualization and writing, and editing.

\section{Bio of Authors}

Dr. GinaMarie Piane, Ph.D., is a Professor of Community Mental Health at the Department of Community Health, College of Professional

\section{References}

[1] Broderick, P.C.\& Blewitt, P. (2015). The Life Span: Human Development for Helping Professionals ( $4^{\text {th }}$ ed.) Pearson, Upper Saddle River, New Jersey.

[2] Charak R., Armour C., Elklit A., Angmo D., Elhai J. D., \& Koot H. M. (2014). Factor structure of PTSD, and relation with gender in trauma survivors from India. European Journal of Psychotraumatology, $\quad 5, \quad 1$. doi:10.3402/ejpt.v5.25547.

[3] Foa, E.B., Zoellner, L.A. \&Feeny, N. C. (2006). An evaluation of three brief programs for facilitating recovery after an assault. J Trauma Stress, 19(1), 29-43.

[4] Frueh, B. C., Monnier, J., Grubaugh, A. L., Elhai, J. D., Yim, E., \& Knapp, R. (2007). Therapist Adherence and Competence with Manualized Cognitive-Behavioral Therapy for PTSD Delivered via Videoconferencing Technology. Behavior Modification, 31(6), 856-866. https://doi.org/10.1177/0145445507302125.

[5] Gillies D, Taylor F, Gray C, O'Brien L, D'Abrew N. Psychological therapies for the treatment of post-traumatic stress disorder in children and adolescents. Cochrane Database of Systematic Reviews 2012, Issue 12. Art. No.: CD006726.

DOI:

10.1002/14651858.CD006726.pub2.

[6] Hien, D., Levin, F., Ruglass, L., \& Lopez-Castro, T. (2015). Enhancing the effects of Cognitivebehavioral therapy for PTSD and alcohol use
Studies, National University, San Diego, California.

Precious Chidozie Azubuike, $\mathrm{BScPH}$, is a Research Assistant and Master of Health Sciences student at the Pan African University of Earth and Life Sciences, Ibadan, Nigeria.

\section{Acknowledgment/Sponsorship}

This was a self-sponsored research/review, and there are no conflicts of interest between the authors.

disorders with antidepressant medication: A randomized clinical trial. Drug and Alcohol Dependence, 146, e142-e142.

[7] Iverson, K. M., Gradus, J. L., Resick, P. A., Suvak, M. K., Smith, K. F., \& Monson, C. M. (2011). Cognitive-behavioral therapy for PTSD and depression symptoms reduces risk for future intimate partner violence among interpersonal trauma survivors. Journal of Consulting and Clinical Psychology, 79(2), 193-202. https://doiorg.nuls.idm.oclc.org/10.1037/a0022512.

[8] Khan, A. M., Dar, S., Ahmed, R., Ramya, B., Mahwish, A., \&Kotapati, V. P. (2018). Cognitive-behavioral therapy versus eye movement desensitization and reprocessing in patients with post-traumatic stress disorder: Systematic review and meta-analysis of randomized clinical trials. Cureus, 10(9) doi: http://dx.doi.org.nuls.idm.oclc.org/10.7759/cureus.3250.

[9] Mcdevitt-Murphy, M., Roberts, M., Barnett, J., \& Sherman, M. (2011). Significant Other Enhanced Cognitive-Behavioral Therapy for PTSD and Alcohol Misuse in OEF/OIF Veterans. Professional Psychology: Research and Practice, 42(1), 40-46. https://doi.org/10.1037/a0022346.

[10] Monson CM, Fredman SJ, Macdonald A, Pukay-Martin ND, Resick PA, Schnurr PP. Effect of Cognitive-Behavioral Couple Therapy for PTSD: A Randomized Controlled Trial. JAMA. 2012;308(7):700-709. doi:10.1001/jama.2012.9307.

[11]National Institute for Mental Health (2019). Post-Traumatic Stress Disorder. Accessed at: 
https://www.nimh.nih.gov/health/statistics/posttraumatic-stress-disorder-ptsd.shtml Accessed on March 27, 2019.

[12] Olff M. (2016). Five years of European Journal of Psychotraumatology. European Journal of Psychotraumatology, $\quad 7, \quad 31350$. doi:10.3402/ejpt.v7.31350.

[13]Pérez Benítez, C., Zlotnick, C., Gomez, J., Rendón, M., \& Swanson, A. (2013). Cognitivebehavioral therapy for PTSD and somatization: an open trial. Behaviour Research and Therapy, 51(6), 284-289. https://doi.org/10.1016/j.brat.2013.02.005. [14] Prochaska, J.O., Norcross, J.C. (2018). Systems of Psychotherapy ( $9^{\text {th }}$ Ed.) New York, NY: Oxford University Press.

[15]Christiansen, D.M., Hansen, M. and Elklit, A. (2014) Correlates of Coping Styles in an Adolescent Trauma Sample. Journal of Child \& Adolescent Trauma, 7, 75-85.

[16]Rose SC, Bisson J, Churchill R, Wessely S. Psychological debriefing for preventing posttraumatic stress disorder (PTSD). Cochrane Database of Systematic Reviews 2002, Issue 2. Art. No.: CD000560.

DOI: 10.1002/14651858.CD000560.
[17] Shnaider, P., Pukay, M. N. D., Fredman, S. J., Macdonald, A., \& Monson, C. M. (2014). Effects of Cognitive-Behavioral Conjoint Therapy for PTSD on Partners' Psychological Functioning. Journal of Traumatic Stress, 27(2), 129-136. https://doiorg.nuls.idm.oclc.org/10.1002/jts.21893.

[18] van der Meer C. A. I., Bakker A., Smit A. S., van Buschbach S., den Dekker M., Westerveld G. J., Olff M. (2017). Gender and age differences in trauma and PTSD among Dutch treatment-seeking police officers. Journal of Nervous \& Mental Disease, 205(2), 87-2. doi:10.1097/NMD.0000000000000562.

[19] Wagner, A., Torbit, L., Jenzer, T., Landy, M., Pukay-Martin, N., Macdonald, A., Monson, C. (2016). The Role of Posttraumatic Growth in a Randomized Controlled Trial of CognitiveBehavioral Conjoint Therapy for PTSD. Journal of Traumatic Stress, 29(4), 379-383. https://doi.org/10.1002/jts.22122.

[20]Zayfert, C., \&Deviva, J. (2004). Residual insomnia following cognitive behavioral therapy for PTSD. Journal of Traumatic Stress, 17(1), 69-73. https://doi.org/10.1023/B:JOTS.0000014679.31799. e7. 